\title{
ROLE CONFLICT OF EMPLOYED WOMEN IN INFORMATION TECHNOLOGY SECTOR
}

\author{
Regeena Thanganila. $\mathbf{W}^{1}$, Thangavel. $\mathrm{N}^{2}$ \\ ${ }^{1}$ Director, ${ }^{2}$ Principal (Management Studies) \\ Jeppiaar Engineering College, Rajiv Gandhi Salai, Chennai - 119 \\ Email: thangavelraj@gmail.com
}

\begin{abstract}
The present social structure reflects the changes that have come through changing frame of time. A major breakthrough is the growing education and economic independence among women. The economic pressures of inflation, influence of the women's movement and the psychological need to develop one's 'self identity' are encouraging the women to take a more active role outside the home to pursue full time careers. This shift from private to public domain gives an impression that women have finally liberated from shackles of patriarchal norms. However, a closer look at the scenario makes us realize that working women face new set of problems involving both family and profession. The present research is carried out to study the effect of different professions and multiplicity of social roles on the role conflict amongst working women those who are working in IT sectors.
\end{abstract}

Key Words: Conflict, Role Conflict, Employed Women, Information Technology, Family Role.

\section{INTRODUCTION}

Conflict is an inescapable aspect of social interactions, an inevitable consequence of the interactions and interdependencies between organizational participants. As Newman pointed out, "Life is' not a grand harmony; conflict exists". In organizations, conflict can take many forms and can stem from many sources. The effective manager must understand the nature of conflict that is beneficial to the organization and conflict that is not. He must deal with conflict in ways that promote both individual and organizational goals. The management of conflict is an essential prerequisite to sound human relations"

Conflict can be a serious problem in an organization. It can create chaotic conditions that make it nearly impossible for employees to work together. On the other hand, as the American team found out too late, conflict also has a positive side. We'll explain the difference between negative and positive conflicts in this chapter and provide a guide to help you understand how conflicts develop. We will also present a topic closely akin to conflict- negotiation. But first, let's clarify what we mean by conflict.

\section{ROLE CONFLICT}

There are situations where the proscribed sets of behavior that characterize roles may lead to cognitive dissonance in individuals. Role conflict is a special form of social conflict that takes place when one is forced to take on two different and incompatible roles at the same time. For example, a person may find conflict between her role as a mother and her role as an employee of a company when her child's demands for time and attention distract her from the needs of her employer. ${ }^{[4]}$ Similarly, role confusion occurs in a situation where an individual has trouble determining which role he or she should play, but where the roles are not necessarily incompatible.

\section{PROBLEM OF THE STUDY}

The women employees are playing various roles not only in the office but also in their home. They have to face variety of problems from both the sources. This has resulted in more stress among the employed women in Information Technology sectors which lead to highly unhealthy and unsafe working environment.

The following are the main reasons for the problems faced by women workers in the IT \& its related sectors:

* Night duty work

* Over time working hours

* Health problem (Digestive diseases, Hair loss, Back pain, Stress. Etc)

* Safety problem

- Culture degradation

* High Sickness Rates

- Repetitive work

* High turnover of employees

- Insufficient breaks 
Regeena Thanganila et al: Role Conflict of Employed Women In Information ...

* Orthopedic problems

* Loss of voice \& Loss of hearing, etc.

Hence this study is attempted to find out various roles played by working women in IT sector and analyze the causes for the role conflicts and also to provide the measures to prevent or to reduce the conflict among the working women.

\section{OBJECTIVES OF THE STUDY}

1. To identify the different roles of women employees in IT sectors.

2. To find out the most important causes of role conflict and remedial measures adopted by the organization.

3. To know the occurrence level of role conflict due to personal and environment Conditions.

4. To identify the type of role conflict exists in the organization.

5. To find out the effects of role conflict on productivity and profitability.

6. To summarize the findings with legitimate measures and to extend valuable Suggestions to prevent conflict to the maximum possible extent.

\section{RESEARCH METHODOLOGY}

Research in common parlance refers to search for knowledge eminent researches have defined research as scientific and systematic search pertinent information on a specific topic. In fact research is the art of scientific investigation. It is actually a voyage of discovery. Research is thus an original contribution to the existing stock of knowledge making for its advancement. In this study the researcher has used non scientific research methodology. The research design, data collection method and sampling plan and sampling procedure are elaborated.

Survey method has been adopted to determine the role conflict among the respondents. The survey has been conducted by questionnaire method, among female respondents in selected IT companies at Chennai city. The sample of the study consists of 936 respondents.

Convenient sample method has been used to select the respondents for the study. The respondents for the study fall in the age group of 20-55 years with educational qualifications ranging from 12th standard to Post graduation / Professional Degree. It includes working respondents with salary ranging from Rs 15,000/- to more than Rs $150,000 /$ -

\section{DATA ANALYSIS AND INTERPRETATION}

This part of the study completely explores the primary data by means of higher order statistical tools. The statistical tools like percentage analysis, analysis of variance, Chi square analysis and Correlation \& Regression analysis are exploited to find the useful results desired in the objectives of the study.

Table 1. Age wise distribution of respondents

\begin{tabular}{|l|c|c|}
\hline Age in years & Number of Respondents & $\%$ \\
\hline Less than 25 & 281 & 30 \\
\hline $25-35$ years & 234 & 25 \\
\hline $36-45$ years & 187 & 20 \\
\hline More than 45 & 234 & 25 \\
\hline Total & 936 & 100 \\
\hline
\end{tabular}

It is inferred that majority of respondents(30\%) have told that they are in the age group of less than 25 years, followed by $25 \%$ in the age group of $25-35$ and more than $45 \%$, and the respondent belonging to $36-45$ is only at $20 \%$.

Table 2. Opinion of women employees about the two important roles

\begin{tabular}{|l|c|c|}
\hline \multicolumn{1}{|c|}{ Roles } & $\begin{array}{c}\text { Number of } \\
\text { respondents }\end{array}$ & $\%$ \\
\hline Family/Home role & 679 & 73 \\
\hline Professional/career role & 257 & 27 \\
\hline Total & 936 & 100 \\
\hline
\end{tabular}

It is clear from the above table that the ratio of female workers who are opting for family/home role is comparatively higher $(73 \%)$ than that of female workers for the other option (27\%). 
Table 3 Showing the Educational Qualification of employees

\begin{tabular}{|l|c|c|}
\hline $\begin{array}{c}\text { Educational } \\
\text { qualification }\end{array}$ & $\begin{array}{c}\text { Number of } \\
\text { respondents }\end{array}$ & $\%$ \\
\hline Diploma & 327 & 35 \\
\hline Degree & 281 & 30 \\
\hline Post graduate & 234 & 25 \\
\hline Professional & 94 & 10 \\
\hline Total & 936 & 100 \\
\hline
\end{tabular}

It is clear that the above table shows that $35 \%$ of employees are diploma qualified, followed by Degree holders at $30 \%$, and the post graduates are at $25 \%$. But the professional's share is only $10 \%$.

Table 4. Showing the experience of respondents

\begin{tabular}{|l|c|c|}
\hline Experience in years & $\begin{array}{c}\text { Number of } \\
\text { respondents }\end{array}$ & $\%$ \\
\hline Upto 3 years & 234 & 25 \\
\hline $4-6$ years & 187 & 20 \\
\hline $7-9$ years & 187 & 20 \\
\hline Above 9 years & 328 & 35 \\
\hline Total & 936 & 100 \\
\hline
\end{tabular}

From the above table, it is found that majority of respondents (35\%) are having the experience of more than 9 years, next to this $25 \%$ are having upto 3 years experience and between $4-9$ years are at $40 \%$.

Table 5 Indicating the salary level of respondents

\begin{tabular}{|l|c|c|}
\hline Monthly Salary level & $\begin{array}{c}\text { Number of } \\
\text { respondents }\end{array}$ & $\%$ \\
\hline Below Rs 25,000 & 281 & 30 \\
\hline Rs. $25000-$ Rs. 50000 & 468 & 50 \\
\hline Above Rs. 50,000 & 187 & 20 \\
\hline Total & 936 & 100 \\
\hline
\end{tabular}

The above table indicates that $50 \%$ of the employees are earning from Rs.25000 - Rs.50, 000,
$30 \%$ of the employees are earning below Rs.25000, but the employees who are earning more than Rs. 50000 are only at $20 \%$.

Table 6. Marital status of respondents

\begin{tabular}{|l|c|c|}
\hline Marital status & Number of respondents & $\%$ \\
\hline Married & 655 & 70 \\
\hline Unmarried & 281 & 30 \\
\hline Total & 936 & 100 \\
\hline
\end{tabular}

It is stated that $70 \%$ of the workers got married, but the unmarried is only $30 \%$.

Table 7. Indicating the reasons for imbalance leading to role Conflict

\begin{tabular}{|l|c|c|}
\hline \multicolumn{1}{|c|}{ Reasons } & $\begin{array}{c}\text { Number of } \\
\text { respondents }\end{array}$ & $\%$ \\
\hline Excessive work & 281 & 30 \\
\hline Safety problems & 131 & 14 \\
\hline Lack of support from superiors & 56 & 6 \\
\hline Insufficient brakes & 468 & 50 \\
\hline Total & 936 & 100 \\
\hline
\end{tabular}

It is evident from the above analysis that, $50 \%$ of the respondents replied, insufficient brakes as the reason for imbalance in their role, followed by $30 \%$ for excessive work, but the safety problem and lack of support from superiors are of $20 \%$.

Table 8. Indicating the level of extent the conflict occurs due to family role

\begin{tabular}{|l|c|c|}
\hline Nature level & Number of respondents & $\%$ \\
\hline Always & 234 & 25 \\
\hline Sometimes & 140 & 15 \\
\hline Rare & 562 & 60 \\
\hline Total & 936 & 100 \\
\hline
\end{tabular}

Nearly $60 \%$ of employees replied that conflict due to family role occurs rarely, followed by $15 \%$ as sometimes, and $25 \%$ of the employees expressed as always. 
Table 9. Conflict due to irregular communication

\begin{tabular}{|c|c|c|}
\hline Response & Number of respondents & $\%$ \\
\hline Yes & 375 & 40 \\
\hline No & 561 & 60 \\
\hline Total & 936 & 100 \\
\hline
\end{tabular}

Majority of respondents $(60 \%)$ have told that they did not get conflict due to irregular communications but $40 \%$ accept that conflicts are due to irregular communications

Table 10. Role Conflict due to dislike of works and insubordination

\begin{tabular}{|l|c|c|}
\hline \multicolumn{1}{|c|}{ Response } & Number of respondents & $\%$ \\
\hline Strongly agree & 187 & 20 \\
\hline Agree & 468 & 50 \\
\hline Neutral & 206 & 22 \\
\hline Disagree & 56 & 6 \\
\hline Strongly disagree & 19 & 2 \\
\hline Total & 936 & 100 \\
\hline
\end{tabular}

A maximum level of employees (70\%) agreed that dislike of work and in-subordination leads to conflict, $22 \%$ of employees kept silence and only $8 \%$ of the employees did not agree with this statement.

\section{MAJOR FINDINGS OF THE STUDY}

- It is found out that there would be an increase in the role conflict with the increasing number of social roles of the working women.

- It is also identified that disproportionate share of household and child care responsibilities in working mothers resulted in home and work responsibilities being placed in opposition to one another and hence leading to role conflict.

- The present findings highlight the importance of quality of job. The profession of an IT employee is highly complicative only after their marriage. Due to change of shift they may not enjoy the life freely to make choices on the job, more control as compared to others.

- It is identified that the work-role that combines highly psychological demanding tasks with low level of control over the tasks exerts a major role by simultaneously creating arousal and frustration.
- It is also identified that women employees working in irregular hours have more problems than those working in regular hours. In both employees and team leaders the timing of duties is too erratic since the moments required are to do night shifts along with call duties whereas their jobs in other sectors require a fixed time schedule that too in the day shift. Therefore little overload allows them comparatively more quality time to be spent in household duties.

- As professional women they are expected to be committed to their work "just like men" at the same time as they are normatively required to give priority to their family.

- Further, the position seems to complicate when the woman attains motherhood. It is known that as the roles increase, so do the responsibilities. High demands sometimes result in less ability to satisfy any responsibility fully and thus the feeling that life is out of control.

\section{MAJOR SUGGESTIONS}

- Offering flexible work arrangements have been one of the most prevalent ways organizations have responded to the changing needs of the work force and these arrangements are predicted to be among the top issues facing the human resources profession in the coming years

- When pressures arising in one role are incompatible with pressures arising in another role, organization must try to avoid forcing their women employees.

- Flexible time arrangements are more strongly related to organizational commitment and job satisfaction for individuals with kinship responsibilities than for those without such responsibilities.

- Organizational policies are designed to help integrate work and family roles are effective in achieving organizational outcomes through their effects on inter-role conflict

- An individual's salient identity (e.g., career vs. family) influenced the attraction to organizations that offered either a traditional "career comes first" career path or a dual career path (where the employee must choose between a paths that puts family first or one that puts career first). 
- It is also suggested that employers might benefit from building flexibility into career path and policies.

- The extent that different work arrangements allow one to minimize the problems associated with managing multiple roles, they should be attractive to working women.

- Suggested that the need for further studies on work-family conflict and coping behavior of married working women will help the organization to have a different strategy to suit the changing trend in the environment.

\section{CONCLUSIONS}

This research contributes in understanding the role conflict in working women in IT sectors with regard to their professions and their family roles. But simply knowing is not enough. Therefore, these findings highlight the need for human relation approach which concerns with 'WHAT' can be done to prevent or resolve the role conflict among the women employees. At the organizational level, approaches may be aimed at improving the work schedule and providing social support while at personal level a change in attitude of people towards working women is required.

The present research underlies the need to sensitize family members and employers of women's job. Meshing of work and family can produce strain, thus couple as unit may negotiate an optimal allocation of roles in order to reduce the pressure endemic to their situation. In this way, the proper sharing of household and child rearing responsibilities and sturdy support may enable these professionals to contribute fruitfully and more effectively at home as well as work place.

\section{BIBLIOGRAPHY}

[1] Barnett, R.C., \& Baruch, G.K. (1985). Women's involvement in multiple roles, and psychological distress. Journal of Personality and Social Psychology, 49, 135-145.

[2] Chattopadhyay, I., \& Dasgupta, S.K. (1999). Good news about role stress(s). Journal of Indian Academy of Applied Psychology, 25, 35-38.

[3] Coser, L. (1974). Greedy Institutions. New York: Free Press.

[4] Emmons, C.A., Biernat, M., Tiedje, L.B., Lang, E., \& Wortman, C.B. (1990). Stress, support, and coping among women professionals with preschool children.
In J. Eckenrode and S. Gore (Eds.), Stress between work and family (pp.61-93). New York: Plenum.

[5] Frone, M.R., Russell, M., \& Cooper, M.L. (1992). Antecendents and outcomes of work-family conflict: Testing a model of work-family interface. Journal of Applied Psychology, 77, 65-78.

[6] Gutek, B.A., Nakamura, C.Y., \& Nieva, V. (1981). The interdependence of work and family roles. Journal of Occupational Behaviour, 2, 1-16.

[7] Haworth, J.T., Jarman, M., \& Lee, S. (1997). Positive psychological states in the daily life of a sample of working women. Journal of Applied Social Psychology, 27, 345-370.

[8] Hemlatha, P., \& Suryanarayana, M. (1983). Married working women: A study on their role interactions. The Indian Journal of Social Work, 9, 153-156.

[9] Holahan, C., \& Gilbert, I. (1979). Conflict between major life roles: Women and men in dual career couples. Human Relations, 32, 451- 467.

[10] Kapur, P. (1974). Changing status of the working women in India. Delhi: Vikas Publishing House Pvt. Ltd.

[11] Pandey, A.K. (1999). Manual for Role conflict scale.Agra: National Psychological Corporation.

[12] Pareek, A., \& Mehta, M. (1997). Role stress among working women. In D.M. Pestonyee, \& U. Pareek (Eds), Studies in Organizational Role Stress and coping (pp. 173-181). New Delhi: Nice.

[13] Paterson, L.R. (1978). An exchange analysis of family roles and marital satisfaction. Diss. Abst. Int., 38, 5746.

[14] Pleck, J.H. (1977). The work-family role system. Social Problems, 24, 417-427.

[15] Rizzo, J.R., House, R.J. \& Lirtzman, S.I.(1970). Role conflict ambiguity in complex organizations. Administrative Science Quaterly, 15,150-163.

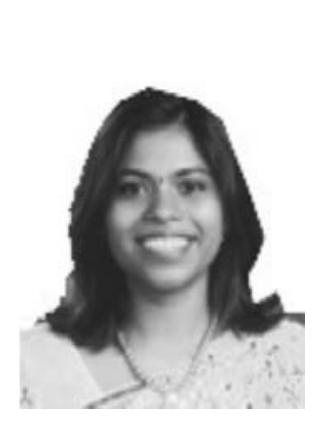

Er. Regeena Wilson is the Director of Jeppiaar Engineering College, Chennai-119. She has coordinated many Conferences including Staff Development Programmes. She has published 5 papers in International and 3 papers in National Journals and presented 10 papers in both International and National

conferences. She is specialized in Women empowerment, Global Strategic Management and Information Technology and she has more focus on Research, Design and Development. 